\title{
HYSTERECTOMY: DIAGNOSIS BEFORE AND AFTER
}

\author{
Jyotsna Deshmukh ${ }^{1}$, Shirish Shanbhag ${ }^{2}$
}

${ }^{1}$ Associate Professor, Department of Obstetrics \& Gynaecology, RCSM Government Medical College, Kolhapur, Maharashtra. 2Professor, Department of Obstetrics \& Gynaecology, RCSM Government Medical College, Kolhapur, Maharashtra.

\section{ABSTRACT}

The present study was undertaken as a model endeavor to correlate between clinical, operative and histopathological diagnoses of hysterectomy cases. Cases where there is a correlation and where there is no correlation between clinical, operative and histopathological diagrams was studied.

\section{KEYWORDS}

Hysterectomy, Clinical Diagnoses, Histopathological Diagnosis.

HOW TO CITE THIS ARTICLE: Deshmukh J, Shanbhag S. "Hysterectomy: Diagnosis before and after." Journal of Evolution of Medical and Dental Sciences 2015; Vol. 4, Issue 104, December 28; Page: 16923-16925, D0I: 10.14260/jemds/2015/2549

\section{INTRODUCTION}

The diagnosis and management of a disease in a female patient often proves to be difficult challenge to meet, because it encompasses a large number of diverse gynecological disorders, ranging from inflammation to tumour to even normal/ectopic pregnancy. Hysterectomy has become a common gynaecological operation because of the safety provided to a patient undergoing hysterectomy; has been increased as a result of use of antibiotic blood transfusion facilities, improved anesthetic and surgical techniques, modern instrumentation, and good ICU care leading to less post-operative morbidity and motility. Under these circumstances, there is a growing tendency to liberalize the indications for a hysterectomy and subsequently there is a real danger of a wrong preoperative diagnosis. The treatment may be correct, but the diagnosis may be wrong. Many a times the operative findings are at a variance with the clinical diagnosis. This is probably because of variations in the mode of presentation of a particular condition and overlap of some of the signs and symptoms between two conditions.

\section{AIMS AND OBJECTIVES}

1. To study the retrospective correlation between clinical diagnosis and diagnosis after investigations.

2. To study correlation between clinical and operative diagnosis.

3. To study correlation between clinical and histopathological diagnosis.

4. To study the percentage where there are correlations and where there are no correlations between the diagnosis.

5. To study the percentage where there was any indication for the removal of the uterus in absence of any appreciable pathological changes.

\section{MATERIALS AND METHODS}

This study was done in gynaecology unit of RCSMGMC Kolhapur for a period of one year. A total number of 125 cases were studied.

Financial or Other, Competing Interest: None.

Submission 05-12-2015, Peer Review 06-12-2015,

Acceptance 24-12-2015, Published 26-12-2015.

Corresponding Author:

Jyotsna Deshmukh,

1557 E, Rajarampuri, $3^{\text {rd }}$ Lane,

Opposite Hotel Castle,

Kolhapur-416008.

E-mail: admanejyo25@yahoo.co.in

DOI:10.14260/jemds/2015/2549
Cases of abdominal and non-prolapse vaginal hysterectomies were included in this study.

\section{Exclusion Criterion}

i. Uterovaginal Prolapse.

ii. Obvious diagnosis of malignancy of uterus, cervix or ovary.

All the cases were evaluated preoperatively. At the first visit, history was taken and patient was examined clinically to note the findings. Every patient was investigated preoperatively for judging her fitness to undergo surgery. Ultrasound examination was carried out in all patients. Preoperative diagnostic dilatation and curettage was done in some patients, such as dysfunctional uterine bleeding in perimenopausal and post-menopausal bleeding. Pap smear was taken in all patients. In suspicious cases of chronic cervical lesion or abnormal pap smear, cervical biopsy was taken to rule out carcinoma of cervix. Each and every patient was evaluated thoroughly by anesthetist. All the specimens were sent to histopathological examination and histopathological report clinched the final diagnosis.

\section{DISCUSSIONS}

A total number of 125 cases were studied retrospectively during this study. Hysterectomy is the second most frequently performed major surgical procedure on women all over the world, next only to Caesarian. In US, approximately 600,000 hysterectomies are performed each year. ${ }^{1} \mathrm{~A}$ study conducted in India stated that incidence of hysterectomy was $7 \%$ among married women, above 15 years of age. ${ }^{2}$ Studies have proved that following hysterectomy women suffer from bothersome psychosexual functions. ${ }^{3}$ Commonest indications for hysterectomy was DUB 51(40.8\%), followed by fibroid $23(18.4 \%)$ and chronic cervicitis $23(18.4 \%)$.

The process of reaching ultimate diagnosis in gynecological case includes proper history taking and clinical examinations, which gives clinical diagnosis, various investigations, laparotomy and finally HPE of the specimen. In this study, dilatations and curettage and pap smear did not help to go nearer the final diagnosis, i.e. the histopathological diagnosis but merely confirmed the clinical diagnosis. The diagnosis of adenomyosis was made in 30 cases in HPE, but it was suspected clinically in one case only. So in cases like adenomyosis, HPE remained the only method to give final diagnosis.

Cervical biopsy was undertaken in 38 cases (30.4\%). The indications was a suspicious chronic cervical lesion. 
In all cases the report came as chronic non-specific cervicitis, while chronic cervicitis was a clinical diagnosis in only 23 cases. So in the remaining 15 cases, cervical biopsy was helpful to go nearer the final diagnosis in time; i.e. HPE, 116 specimens showed chronic nonspecific cervicitis; i.e. if the number of cervical biopsies done preoperatively were more, we could have reached nearer to the final diagnosis before opening the abdomen in more number of cases. According to the Magon et al. hysterectomy is a surgery which has been used and misused, underused and abused at different times in gynaecology. ${ }^{4}$ As any surgical procedure is associated with a risk of complications, the indication should be carefully evaluated. ${ }^{5}$

\section{CONCLUSION}

Hysterectomy is used commonly to improve the quality of life; however, at times it is a life saving procedure. As any surgical procedure, it is associated with a risk of complications, so the indication should be carefully evaluated with the emergence of many conservative approaches to deal with benign gynecological conditions, it is prudent to discuss available options with the patient before taking a direct decision of surgically removing the uterus.

\section{REFERENCES}

1. Wu JM, Wechter ME, Geller EJ, et al. "Hysterectomy rates in the United States, 2003," Obstetrics and Gynecology, Vol. 110, no. 5, PP. 1091 - 1095, 2007. View at Publisher. View at Google Scholar. View at Scopus.

2. Singh A and Arora AK. "Why hysterectomy rate are lower in India?" Indian Journal of Community Medicine, Vol. 33, no. 3 PP. 196-197, 2008. View at Publisher, View at Google Scholar.

3. McPhorson K, Herbert A, Judge A, et al. "Pshyco-sexual health 5 years after hysterectomy: Population based comparison with endometrial ablation for dysfunctional uterine bleeding." Health Expectations, Vol. 8 No. 3, PP. 234-243, 2005. View at Publisher. View at Google Scholar. View at Scopus.

4. Magon N, Divakar H and Kriplani A. "Editorial: the use, misuse and abuse of hysterectomy." Journal of Mid Life Health, Vol. 4, No. 1, 2013. View at Google Scholar.

5. Nieboer TE, Johnson N, Lethaby A, et al. "Surgical approach to hysterectomy for benign gynecological diseases." Cochrane Database of Systematic Reviews, No. 3, Article ID CD003677, 2007. View at Publisher. View at Google Scholar. View at Scopus.

\begin{tabular}{|c|c|c|c|}
\hline $\begin{array}{c}\text { Sl. } \\
\text { No. }\end{array}$ & DIAGNOSIS & $\begin{array}{c}\text { NO. } \\
\text { OF } \\
\text { CASES }\end{array}$ & PERCENTAGE \\
\hline 1. & $\begin{array}{c}\text { Dysfunctional uterine } \\
\text { bleeding }\end{array}$ & 51 & 40.8 \\
\hline 2. & Fibroid & 23 & 18.4 \\
\hline 3. & Chronic cervicitis & 23 & 18.4 \\
\hline 4. & Ovarian cyst & 16 & 12.8 \\
\hline 5. & Tubo-ovarian mass & 4 & 3.2 \\
\hline 6. & Pelvic Inflammatory & 6 & 4.8 \\
\hline 7. & Disease & 1 & 0.81 \\
\hline 8. & Adenomyosis & 1 & 0.81 \\
\hline \multicolumn{3}{|c|}{ Table 1: Clinical Indications for Hysterectomy } \\
\hline \multicolumn{2}{|c|}{ Total } & 125 & $\mathbf{1 0 0 . 0 0 \%}$ \\
\hline
\end{tabular}

The most common clinical indication for hysterectomy was DUB, followed by fibroid and chornic cervicitis.

\begin{tabular}{|c|c|c|c|}
\hline $\begin{array}{c}\text { Sl. } \\
\text { No. }\end{array}$ & DIAGNOSIS & $\begin{array}{c}\text { NO. } \\
\text { OF } \\
\text { CASES }\end{array}$ & PERCENTAGE \\
\hline 1. & $\begin{array}{c}\text { Dysfunctional uterine } \\
\text { bleeding }\end{array}$ & 51 & $40.8 \%$ \\
\hline 2. & Fibroid & 18 & $14.4 \%$ \\
\hline 3. & Chronic cervicitis & 23 & $18.4 \%$ \\
\hline 4. & Ovarian cyst & 13 & $10.4 \%$ \\
\hline 5. & Tubo-ovarian mass & 4 & $3.2 \%$ \\
\hline 6. & $\begin{array}{c}\text { Pelvic Inflammatory } \\
\text { Disease }\end{array}$ & 6 & $4.8 \%$ \\
\hline 7. & Adenomyosis & 1 & $0.8 \%$ \\
\hline 8. & Dermoid cyst & 1 & $0.8 \%$ \\
\hline \multicolumn{4}{|c|}{ Table 2: Intraoperative Diagnosis } \\
\hline
\end{tabular}

Findings in cases of DUB or chronic cervicitis were consistant with the clinical diagnosis, while in cases of fibroid or ovarian cyst diagnosis differed from clinical diagnosis to some extent. Fibroid was misdiagnosed in $21.73 \%$ and ovarian cyst was misdiagnosed clinically in $18.75 \%$ cases.

\begin{tabular}{|c|c|c|c|}
\hline $\begin{array}{c}\text { Sl. } \\
\text { No. }\end{array}$ & DIAGNOSIS & $\begin{array}{c}\text { NO. } \\
\text { OF } \\
\text { CASES }\end{array}$ & PERCENTAGE \\
\hline 1. & $\begin{array}{c}\text { Dysfunctional uterine } \\
\text { bleeding }\end{array}$ & 38 & $31.4 \%$ \\
\hline 2. & Fibroid & 18 & $14.4 \%$ \\
\hline 3. & Chronic cervicitis & 116 & $92.8 \%$ \\
\hline 4. & Ovarian cyst & 13 & $10.4 \%$ \\
\hline 5. & Tubo-ovarian mass & 4 & $3.2 \%$ \\
\hline 6. & $\begin{array}{c}\text { Pelvic Inflammatory } \\
\text { Disease }\end{array}$ & 6 & $4.8 \%$ \\
\hline 7. & Adenomyosis & 30 & $24.0 \%$ \\
\hline 8. & Dermoid cyst & 1 & $0.8 \%$ \\
\hline \multicolumn{3}{|c|}{ Table 3: Histopathological Diagnosis } \\
\hline
\end{tabular}

Histopathological diagnosis is the final diagnosis. The percentage of clinical diagnosis and histopathological diagnosis differs most commonly in cases of chronic cervicitis and adenomyosis and DUB.

\begin{tabular}{|c|c|c|c|c|}
\hline $\begin{array}{c}\text { SI. } \\
\text { No. }\end{array}$ & DIAGNOSIS & $\begin{array}{c}\text { NO. } \\
\text { OF } \\
\text { CASES }\end{array}$ & $\begin{array}{c}\text { CLIN } \\
\text { DIAGNOSED }\end{array}$ & $\begin{array}{c}\text { PERCENTAGE } \\
\text { RELIABILITY }\end{array}$ \\
\hline 1. & $\begin{array}{c}\text { Dysfunctional } \\
\text { uterine } \\
\text { bleeding }\end{array}$ & 38 & 51 & $74.5 \%$ \\
\hline 2. & Fibroid & 13 & 23 & $78.26 \%$ \\
\hline 3. & $\begin{array}{c}\text { Chronic } \\
\text { cervicitis }\end{array}$ & 116 & 23 & $19.82 \%$ \\
\hline 4. & Ovarian cyst & 13 & 16 & $81.25 \%$ \\
\hline 5. & $\begin{array}{c}\text { Tubo-ovarian } \\
\text { mass }\end{array}$ & 4 & 4 & $100 \%$ \\
\hline 6. & $\begin{array}{c}\text { Pelvic } \\
\text { Inflammatory } \\
\text { Disease }\end{array}$ & 6 & 6 & $100 \%$ \\
\hline 7. & Adenomyosis & 30 & 1 & $3.33 \%$ \\
\hline 8. & Dermoid cyst & 1 & 1 & $100 \%$ \\
\hline \multicolumn{5}{|c|}{ Table 4: Diagnostic Reliability } \\
\hline \multicolumn{5}{|c|}{ of Clinical Diagnosis } \\
\hline
\end{tabular}

Diagnostic reliability of TO mass and PID was $100 \%$, while it was least, i.e. only $3.33 \%$ in cases of Adenomyosis. 
Original Article

\begin{tabular}{|c|c|c|c|c|c|c|c|}
\hline $\begin{array}{c}\text { Sl. } \\
\text { No. }\end{array}$ & $\begin{array}{c}\text { DIAGNOSTIC } \\
\text { LEVELS }\end{array}$ & $\begin{array}{c}\text { TOTAL } \\
\text { NO. OF } \\
\text { CASES }\end{array}$ & $\begin{array}{c}+ \text { +VE CORRLN } \\
\text { WITH HPE }\end{array}$ & $\begin{array}{l}\text { \%+VE } \\
\text { WITH HPE }\end{array}$ & $\begin{array}{c}\text {-VE CORRLN } \\
\text { WV }\end{array}$ & IMPROVEMENT \\
\hline 1. & Clinical diagnosis & 125 & 83 & $66.4 \%$ & 42 & $33.6 \%$ & - \\
\hline 2. & Investigation & & & & & & \\
\hline & a. Cervical Biopsy & 38 & 38 & $100 \%$ & 0 & $0 \%$ & $33.6 \%$ \\
\hline & b. D \& C & 51 & 51 & $100 \%$ & 0 & $0 \%$ & $33.6 \%$ \\
\hline & c. USG & 125 & 102 & $81.6 \%$ & 8.19 & $04 \%$ & $14.55 \%$ \\
\hline & d. Pap & 125 & 125 & $100 \%$ & - & - & - \\
\hline 3. & Opperative & 125 & 100 & $80 \%$ & 135 & $108 \%$ & $13.6 \%$ \\
\hline 4. & HPE diagnosis & 125 & 125 & $100 \%$ & 0 & $0 \%$ & $33.6 \%$ \\
\hline
\end{tabular}

Negative correlation includes cases in which final diagnosis was missed or wrongly diagnosed. In number of cases, hysterectomy was done under the pretext of one diagnosis; however, for histopathological examination one or two other pathological conditions were also diagnosed to be co-existing and hence the number of cases with negative correlation with the final diagnosis is more than the study group due to overlap. The most common additional condition was chronic cervicitis co-existing with other condition. 